\title{
Functional Contribution of Chorismate Synthase, Anthranilate Synthase, and Chorismate Mutase to Penetration Resistance in Barley-Powdery Mildew Interactions
}

\author{
Pingsha Hu, ${ }^{1,2}$ Yan Meng, ${ }^{2}$ and Roger P. Wise ${ }^{1,2,3}$ \\ ${ }^{1}$ Interdepartmental Genetics Program, lowa State University, ${ }^{2}$ Department of Plant Pathology and Center \\ for Plant Responses to Environmental Stresses, lowa State University, and ${ }^{3}$ Corn Insects and Crop Genetics Research, \\ United States Department of Agriculture-Agricultural Research Service, lowa State University, Ames 50011-1020, U.S.A.
}

Submitted 12 August 2008. Accepted 5 November 2008.

Plant processes resulting from primary or secondary metabolism have been hypothesized to contribute to defense against microbial attack. Barley chorismate synthase $(H v C S)$, anthranilate synthase $\alpha$ subunit $2(H v A S a 2)$, and chorismate mutase 1 (HvCMI) occupy pivotal branch points downstream of the shikimate pathway leading to the synthesis of aromatic amino acids. Here, we provide functional evidence that these genes contribute to penetration resistance to Blumeria graminis f. sp. hordei, the causal agent of powdery mildew disease. Single-cell transientinduced gene silencing of $\mathrm{HvCS}$ and $\mathrm{HvCM1}$ in mildew resistance locus a (Mla) compromised cells resulted in increased susceptibility. Correspondingly, overexpression of $\mathrm{HvCS}, \mathrm{HvASa}$, and $\mathrm{HvCM1}$ in lines carrying mildew resistance locus $o$ (Mlo), a negative regulator of penetration resistance, significantly decreased susceptibility. Barley stripe mosaic virus-induced gene silencing of $\mathrm{HvCS}, \mathrm{HvASa}$, and HvCM1 significantly increased $B$. graminis f. sp. hordei penetration into epidermal cells, followed by formation of haustoria and secondary hyphae. However, sporulation of B. graminis f. sp. hordei was not detected on the silenced host plants up to 3 weeks after inoculation. Taken together, these results establish a previously unrecognized role for the influence of $\mathrm{HvCS}, \mathrm{HvASa2}$, and $\mathrm{HvCM1}$ on penetration resistance and on the rate of $B$. graminis f. sp. hordei development in Mla-mediated, barley-powdery mildew interactions.

The plant immune system plays a crucial role in preventing microbial invasion and growth. Pathogen-associated molecular patterns (PAMPs) are presented by diverse pathogens which trigger the activation of nonspecific basal defense mechanisms.

Corresponding author: Roger P. Wise; Telephone: +1.515 .294 .9756 ; Fax: +1.515.294.9420; E-mail: rpwise@ iastate.edu

Nucleotide sequence data is available in the GenBank database under accession numbers EU828765 (HvCM1), EU828766 (HvASa2), and EU828767 (HvCS).

* The $e$-Xtra logo stands for "electronic extra" and indicates that one supplemental figure and two supplemental tables are published online.

This article is in the public domain and not copyrightable. It may be freely reprinted with customary crediting of the source. The American Phytopathological Society, 2009.
These responses include the transcription of thousands of stress-related genes as well as the induction of antimicrobial metabolites and peptides during early stages of pathogen invasion. By contrast, effector-triggered immunity generally follows gene-for-gene interactions, where a specific resistance $(\mathrm{R})$ protein initiates a signal cascade when it recognizes, either directly or indirectly, its corresponding avirulence (AVR) effector delivered by an invading pathogen (Flor 1971; Jones and Dangl 2006). Whereas specific $R$ protein-AVR effector recognition often leads to rapid hypersensitive cell death at the invasion site (Boyd et al. 1995; Caldo et al. 2004; Jørgensen 1994; Thordal-Christensen et al. 1997), nonspecific PAMP-triggered immunity may confer quantitative defense against a wider range of pathogens (Jones and Takemoto 2004). In barley-powdery mildew interactions, basal defense responses, such as early autofluorescence and cytoplasmic aggregation in the host cell subjacent to the conidium, are detected as early as $2 \mathrm{~h}$ after a fungal spore lands on the plant surface (Aist and Bushnell 1991). By contrast, $\mathrm{R}$ proteins appear to function 14 to $20 \mathrm{~h}$ after inoculation (hai) after appressorium peg penetration into host epidermal cells (Aist and Bushnell 1991; Boyd et al. 1995; Ellingboe 1972).

Secondary metabolites are nonessential components for the primary metabolic process but are required for plant development and environmental responses. Components of secondary metabolic function, such as alkaloids, isoflavonoids, lignin, and indole-derivatives, play important roles in pathogen resistance (Fig. 1). For example, in the pea-Nectria haematococca interaction, pea produces the isoflavonoid antimicrobial product pisatin. Pathogenicity is dependent on fungal pisatin demethylating ability (PDA) genes to detoxify pisatin (Reimmann and VanEtten 1994). Moreover, deficiency of certain antimicrobial end products often results in enhanced susceptibility in compatible interactions. The Arabidopsis phytoalexin deficiency (pad) mutants that interfere with camalexin biosynthesis result in enhanced susceptibility to the necrotrophic fungi Alternaria brassicicola (Nafisi et al. 2007; Thomma et al. 1999) and Botrytis cinerea (Ferrari et al. 2007).

The diversity in the makeup of metabolites in different species makes it difficult to derive a general mechanism of plant defense. In order to characterize conserved functions in the defense response, we focused on the pivotal enzyme chorismate synthase (CS) (EC 4.2.3.5), as well as its downstream branchpoint enzymes, anthranilate synthase (AS) (EC 4.1.3.27) and chorismate mutase (CM) (EC 5.4.99.5). CS is a key enzyme in 
the synthesis of aromatic amino acids (Fig. 1). CS converts 5enolpyruvylshikimate-3-phosphate (EPSP) into chorismate, which is the common precursor for the phenylalanine/tyrosine (Phe/Tyr) or tryptophan (Try) biosynthetic pathways. CM catalyzes conversion of chorismate to prephenate, the first regulatory step in Phe/Tyr biosynthesis. In higher plants, there are usually two or three CM isoenzymes located in different subcellular compartments, as well as possessing unique enzyme kinetics (d'Amato et al. 1984; Eberhard et al. 1996; Mobley et al. 1999). CM1 and CM3 are feedback-inhibited by free Phe and Tyr but activated by Trp, whereas CM2 is insensitive to any of the three amino acids (Eberhard et al. 1996; Gilchrist et al. 1972; Kuroki and Conn 1988; Mobley et al. 1999). AS, composed of $\alpha$ and $\beta$ subunits, is a branch-point enzyme converting chorismate to anthranilate, leading to the synthesis of Trp and other indole alkaloid derivatives. The $\alpha$ subunit has a catalytic domain of anthranilate synthesis and feedback regulatory domain for Trp inhibition. The AS $\beta$ subunit serves as a holoenzyme, supplying a nitrogen donor via glutamine and ammonia. In plants, the AS $\alpha$ subunit has two isoforms, $\alpha 1$ and $\alpha 2$ (Bohlmann et al. 1996; Niyogi and Fink 1992; Tozawa et al. 2001). In Arabidopsis and Ruta graveolens, AS $\alpha 2$ is sensitive to Trp feedback inhibition while AS $\alpha 1$ is elicitor inducible and insensitive to free Trp (Bohlmann et al. 1996; Niyogi and Fink 1992).

In this study, we present functional analysis of genes encoding three pivotal metabolic enzymes in barley-powdery mildew interactions in the presence or absence of the mildew resistance locus a (Mla) resistance gene. We provide evidence for a previously unrecognized role of $H v C S, H v A S a 2$, and $H v C M 1$ in penetration resistance to Blumeria graminis f. sp. hordei. We also show that these genes influence the rate of $B$. graminis f. sp. hordei development in Mla-mediated barleypowdery mildew interactions.

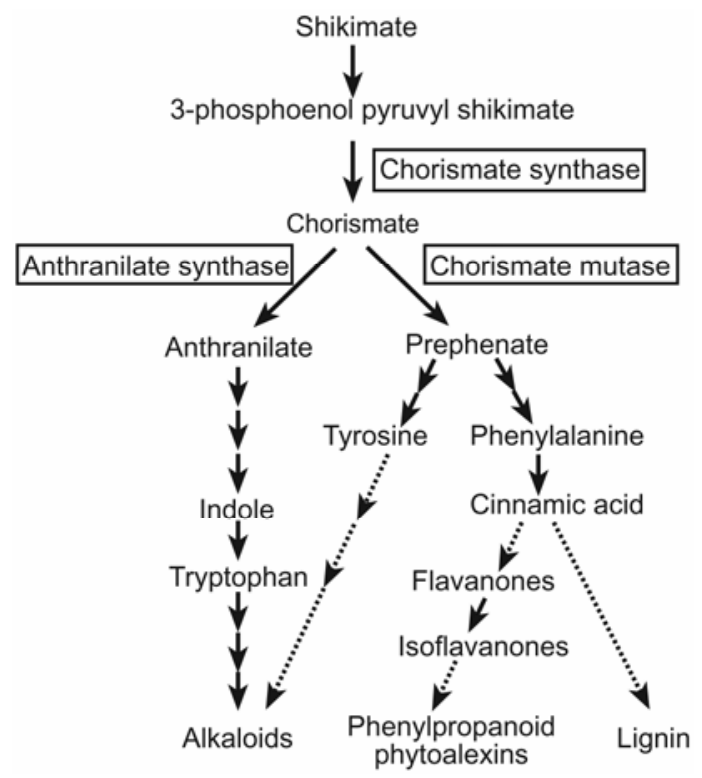

Fig. 1. Biosynthetic pathways leading to the production of secondary metabolites and antimicrobial compounds. Antimicrobial products derived from secondary metabolism are highly induced during the plant immune response (Dixon 2001; Glazebrook and Ausubel 1994), including phenylpropanoid and lignin derivatives during the defense response of barley to Blumeria graminis f. sp. hordei (Aist et al. 1988; Burhenne et al. 2003; Caldo et al. 2006; von Ropenack et al. 1998). The three (boxed) candidate genes, chorismate synthase (cs), anthranilate synthase (as), and chorismate mutase $(\mathrm{cm})$, are differentially expressed in the comparison of compatible versus incompatible interactions of barley with $B$. graminis f. sp. hordei.

\section{RESULTS}

Previously, we utilized the 22K Affymetrix Barley1 GeneChip to analyze time-course expression profiles among incompatible and compatible interactions between barley and powdery mildew. In each of three independent biological replications, a three-by-two matrix design of three near-isogenic lines, harboring introgressed Mla1, Mla6, and Mla13 coiled-coil nucleotide-binding site leucine-rich repeat resistance alleles, were challenged with either $B$. graminis f. sp. hordei isolate $5874\left(A V R_{a l}\right.$ and $\left.A V R_{a 6}\right)$ or $\mathrm{K} 1\left(A V R_{a 1}\right.$ and $\left.A V R_{a 13}\right)$ and harvested at $0,8,16,20,24$, and 32 hai for a total of 108 (host $\times$ pathogen $\times$ time) experimental units (Caldo et al. 2004).

In all, 22 differentially expressed genes in compatible and incompatible barley-B. graminis f. sp. hordei interactions were identified by a mixed linear model at a cutoff $P$ value $<0.0001$ and a false discovery rate (FDR) $<7 \%$. Transcript accumulation of the identified genes was equivalent in both interactions from 0 to 16 hai, when $B$. graminis f. sp. hordei conidiospores germinate and appressoria are formed. Later, during establishment of the perihaustorial interface between penetrating $B$. graminis $\mathrm{f}$. sp. hordei and host epidermal cells, divergent expression of these transcripts occurs, where compatible interactions lead to lower accumulation of transcripts compared with paired incompatible interactions. Many of the 22 genes are positioned at various steps in the shikimate and its downstream amino acid biosynthesis pathway (Caldo et al. 2004, 2006). Therefore, we focused on the pivotal branch-point enzymes chorismate synthase $(H v C S)$ (represented by probeset Barley1_05108), chorismate mutase 1 (HvCM1) (represented by probeset Barley1_07705), and anthranilate synthase $\alpha$ subunit 2 (HvASa2) (represented by probeset Barley1_48443) for further investigation.

\section{Phylogeny of $B$. graminis f. sp. hordei-inducible $\mathrm{HvASa} 2$ and $\mathrm{HvCM1}$.}

In higher plants, genes encoding the $\alpha$ subunit of both anthranilate synthase and chorismate mutase have two or more copies, which differentiate into two major groups: genes associated with steady-state functions of the cell and genes that are induced by stress (Bohlmann et al. 1996; Matsukawa et al. 2002; Mobley et al. 1999; Tozawa et al. 2001). In barley, there are also two anthranilate synthase $\alpha$ subunits, HvASal (Barley1_11179) and HvASa2 (Barley1_48443), and two chorismate mutase genes, $\mathrm{HvCM1}$ (Barley1_07705) and HvCM2 (Barley1_17185), among which HvASa2 and $H v C M 1$ have been identified as significantly differentially expressed in compatible versus incompatible interactions (Caldo et al. 2004). Based on phylogenetic analysis, $\mathrm{HvASa} 2$ is closely related to OsASa2, which is also elicitor inducible (Fig. 2A) (Tozawa et al. 2001). $H v C M 1$ is in a monophyletic clade with Arabidopsis elicitor-inducible AtCMI (Fig. 2B). Both HvASal and HvCM2 fall in clades with elicitor noninducible genes (Fig. 2A and B). The above phylogenetic results confirm previous Barley1 GeneChip expression analysis, indicating that elicitor-inducible and not housekeeping isoforms are likely candidates involved in defense against B. graminis f. sp. hordei (Caldo et al. 2004).

\section{Functional analysis of $\mathrm{HvCS}, \mathrm{HvCM1}$, and $\mathrm{HvASa} 2$ via transient-induced gene silencing.}

Because $H v C S, H v A S a 2$, and $H v C M 1$ were differentially expressed in compatible versus incompatible interactions, we were interested to test whether the resistant phenotype would be compromised upon silencing of these genes. We utilized an RNAi-based, transient-induced gene silencing (TIGS) assay to functionally test these three genes in barley-powdery mildew interactions (Douchkov et al. 2005). TIGS is a high-throughput single-cell assay by which one can evaluate hundreds of trans- 
formed cells in a single experiment. Hairpin constructs of candidate gene fragments are co-bombarded with a Ubi: $\beta$-glucuronidase (GUS) expression vector into barley epidermal cells. Because host cell-B. graminis f. sp. hordei interactions are mainly a cell-autonomous event, lack of $B$. graminis f. sp. hordei haustoria indicates proper resistance activity whereas presence of haustoria indicates that the single cell silenced for the target gene compromises host resistance (Schweizer et al. 2000; Shirasu et al. 1999a). The penetration efficiency is calculated as the ratio of transformed susceptible cells to the total transformed cells attacked by $B$. graminis f. sp. hordei, thus quantifying the influence of silencing candidate genes. $H v C S$, $H v A S a 2$, and $H v C M 1$ gene fragments were cloned into the hairpin vector, pIPKTA30 (Douchkov et al. 2005), and were designated as hpCS, hpASa2, and hpCM1, respectively. The hairpin constructs were co-bombarded with a Ubi:GUS expression vector into barley epidermal cells and transformed cell-B. graminis f. sp. hordei interaction phenotypes were ex-

A

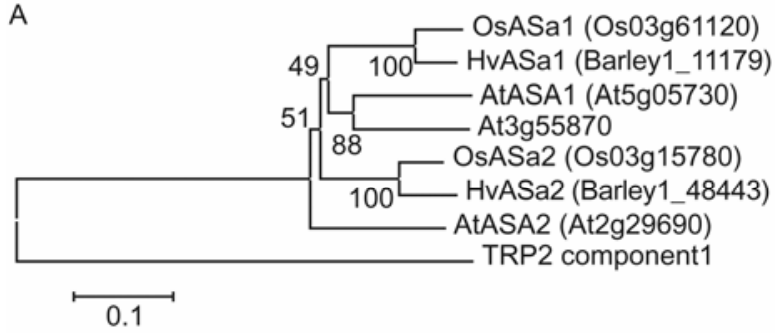

B

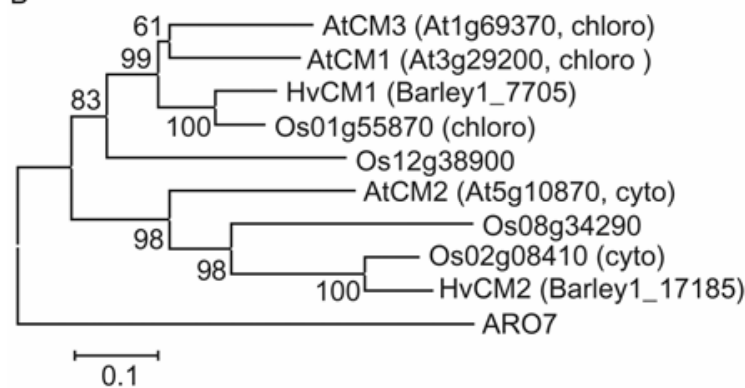

Fig. 2. Phylogenetic analysis of plant anthranilate synthase $\alpha$ subunit and chorismate mutase. A, Peptide sequences of anthranilate synthase $\alpha$ subunit and $\mathbf{B}$, chorismate mutase were used for phylogenetic tree construction by the neighbor-joining method with 1,000 bootstrap replicates. Trees were rooted using $\mathbf{A}$, yeast anthranilate synthase TRP component I and $\mathbf{B}$, chorismate mutase ARO7. Gene locus identifiers and Barley1 exemplar names are indicated in parentheses. Subcellular localization in the cytosol or chloroplast are designated as cyto or chloro, respectively. Bootstrap values are shown at nodes. Branch length represents number of amino acid substitutions per site. amined after GUS staining. In all, 12,651 individual GUSmarked cells were scored from three independent replications of the experiment. Silencing of individual $\mathrm{HvCS}, \mathrm{HvCM1}$, or HvASa2 in barley C.I. 16151 (Mla6) cells did not compromise resistance compared with the empty vector control in the barley-B. graminis f. sp. hordei incompatible interaction (Table 1). However, because the $R$ gene, Mla6, is a strong resistance component, we inferred that the metabolic gene-mediated defense is overridden by the function of Mla6 in the incompatible interaction. We hypothesized that, by silencing these genes in cells where Mla6 had been compromised, cells might become super susceptible, as shown by increased penetration efficiency. We used a $B$. graminis f. sp. hordei-susceptible fast-neutron mutant, mla6-m9472 (Meng et al. 2009), to investigate whether GUS-marked barley cells become supersusceptible when transformed with $h p C S, h p A S a 2$, or $h p C M 1$. However, variation in penetration efficiency among replicates was larger than $25 \%$ in the $B$. graminis f. sp. hordei-susceptible, mla6- $m 9472$ genotype, which made it difficult to make any significant inference. We encountered the same intrinsic variation in penetration efficiency when using the $B$. graminis f. sp. hordei-susceptible rarl-1 and rarl-2 mutants (Freialdenhoven et al. 1994; Shirasu et al. 1999b) that interfere with MLA protein stability (Bieri et al. 2004). Therefore, we decided to investigate these genes by silencing Mla6 in the resistant line, C.I. 16151, to generate single GUS-marked, compromised cells to alleviate the influence of surrounding susceptible cells in our assay.

Epidermal cells silenced for $H v C S, H v C M 1$, or $H v A S a 2$ in combination with Mla6 were approximately 10 to $20 \%$ more susceptible compared with silencing Mla6 only, as shown by the difference in penetration efficiency (Table 1). A significant difference in penetration efficiency was observed by silencing $H v C M 1$ together with Mla6 or HvCS with Mla6 compared with silencing Mla6 alone, with $P$ values of 0.044 and 0.0011 , respectively (Table 1). However, experiments to silence $\mathrm{HvASa2}$ combined with Mla6 resulted in a nonsignificant $P$ value of 0.0614 , suggesting that the Tyr/Phe biosynthetic pathway may contribute incrementally more to defense than the Trp pathway in the barley-B. graminis f. sp. hordei interaction. The combined effects of $H v C S, H v C M 1$, and $H v A S a 2$ genes are shown in Table 2. A combination of hpCS with hpCM1, hpCS with hpASa2, or hpCM1 with hpASa2 showed no significant difference in susceptibility compared with the empty vector control. Including hpMla6 in the combinations increased the penetration index approximately $10 \%$ compared with silencing Mla6 only. All the combinations with hpMla6 showed highly significant differences in susceptibility compared with silencing Mla6 alone, with cutoff $P$ values of $<0.001$ (Table 2). It should be noted that silencing becomes less efficient as more constructs are co-transferred into plant cells (Douchkov et al. 2005). This may explain

Table 1. Blumeria graminis f. sp. hordei penetration efficiency (PE) in transient-induced gene silencing assay I

\begin{tabular}{|c|c|c|c|c|c|}
\hline \multirow[b]{2}{*}{ Construct } & \multicolumn{2}{|c|}{ Number of cells ${ }^{a}$} & \multirow[b]{2}{*}{$\mathbf{P E}^{\mathrm{d}}$} & \multicolumn{2}{|c|}{$P$ value $^{\text {b }}$} \\
\hline & Attacked $^{\mathrm{c}}$ & With haustoria & & Empty vector vs. others & hpMla6 vs. others \\
\hline pIPKTA30 & 375 & 15 & 2.61 & n.a. & $<0.0001$ \\
\hline hpAS & 465 & 12 & 2.28 & 0.4486 & $<0.0001$ \\
\hline $\mathrm{hpCM}$ & 465 & 33 & 6.5 & 0.8661 & $<0.0001$ \\
\hline $\mathrm{hpCS}$ & 588 & 12 & 1.76 & 0.9481 & $<0.0001$ \\
\hline hpMla6 & 621 & 249 & 39.54 & $<0.0001$ & n.a. \\
\hline hpMla6 + hpAS & 1,197 & 597 & 49.52 & $<0.0001$ & 0.0614 \\
\hline hpMla6 + hpCM & 1,455 & 804 & 56.05 & $<0.0001$ & 0.0044 \\
\hline hpMla6 + hpCS & 864 & 531 & 59.36 & $<0.0001$ & 0.0011 \\
\hline
\end{tabular}

${ }^{a}$ Raw numbers indicate the combined total of three independent experiments.

${ }^{\mathrm{b}} P$ values were obtained using a mixed linear model to test for a significant difference of the PE by comparing the test constructs versus the empty vector negative control or the hpMla6 positive control. A $P$ value $<0.05$ indicates that the PEs are significantly different; $\mathrm{n} . \mathrm{a} .=$ not available.

c Attacked with B. graminis f. sp. hordei.

${ }^{\mathrm{d}} \mathrm{PE}$ is shown as the mean of the PE from three independent replications. 
why there is no increase in penetration efficiency when silencing multiple genes in combination with Mla6 compared with silencing a single gene and Mla6. The above results illustrate that silencing both chorismate synthase and chorismate mutase make possible B. graminis f. sp. hordei penetration, implying that branches of the aromatic amino acid biosynthesis pathway leading to lignin and phenylpropanoid phytoalexins contribute to plant defense.

\section{Virus-induced gene silencing of $\mathrm{HvCS}, \mathrm{HvASa}$, and $\mathrm{HvCM1}$ increase formation of $B$. graminis f. sp. hordei secondary hyphae but not conidiation in Mla6-mediated resistant plants.}

The use of Barley stripe mosaic virus-induced gene silencing (BSMV-VIGS) has been shown to be an effective tool for reverse genetic functional analysis in whole seedling leaves (Hein et al. 2005; Scofield et al. 2005). In contrast to the singlecell TIGS assay, BSMV-VIGS can be used to silence large contiguous regions and, therefore, is useful for investigation of non-cell-autonomous effects. In this study, the BSMV-VIGS system was modified by cloning each of the three BSMV subgenome segments into an expression vector with the $35 \mathrm{~S}$ promoter (Meng et al. 2009). The modified BSMV constructs are optimized for biolistic transformation and eliminate the need for in vitro transcription reactions. First, empty virus vector BSMVm:00 and BSMVm:PDS, which carries a fragment of the phytoene desaturase (PDS) gene in its $\gamma$ genome segment, were examined for silencing efficiency. Seven-day-old barley seedlings were infected with BSMVm:00 or BSMVm:PDS via bombardment. The chlorotic mosaic symptoms of BSMV infection were first detectable on the second leaf by 6 days after bombardment (dab). The chlorotic infection symptom was also displayed on the tip of the third leaf approximately 10 to 12 dab. Mosaic symptoms were rarely observed on the fourth leaf. Consistent with virus infection symptoms, BSMVm:PDS, which results in a photobleaching phenotype after silencing, was visible 7 to 9 dab on the second leaf and the tip of the third leaf 12 to 14 dab. Therefore, at 9 dab, barley second leaves were used for investigation in VIGS experiments.

To study the function of $H v C S, H v A S a 2$, and $H v C M 1$ in barley-B. graminis f. sp. hordei interactions, the $H v C S, H v A S a 2$, and $H v C M 1$ gene fragments were cloned into the BSMV $\gamma$ subgenome and designated as BSMVm:CS, BSMVm:AS, and BSMVm:CM, respectively (discussed below). B. graminis f. sp. hordei resistance gene Mla6 was also cloned into the virus as BSMVm:Mla6, which served as a positive control. At 9 dab, second leaves of BSMV-VIGS-treated barley cv. C.I. 16151 (Mla6) were inoculated with $B$. graminis f. sp. hordei isolate $5874\left(A V R_{a 6}\right)$. Seven days after inoculation (dai) with $B$. graminis f. sp. hordei, plants were scored for infection types.
Negative control plants infected with BSMVm:00 displayed the typical C.I. 16151 (Mla6)-mediated resistant infection type, whereas the positive control infected with BSMVm:Mla6 exhibited typical susceptible symptoms with $B$. graminis f. sp. hordei sporulation on the leaf surface (Fig. 3). When plants were inspected macroscopically, no colonization of B. graminis f. sp. hordei was detected up to 3 weeks after inoculation of plants infected with BSMVm:CS, BSMVm:AS, and BSMVm:CM (Fig. 3). However, at the microscopic level, BSMVm:CS-, BSMVm:AS-, and BSMVm:CM-treated plants displayed elongating secondary hyphae (ESH) at 72 hai (Fig. 4), indicating functional haustoria within the epidermal cell (Ellingboe 1972). A susceptibility index was calculated as the ratio of cells with haustoria to the total cells attacked by $B$. graminis f. sp. hordei in silenced regions (discussed below). Barley leaves treated with BSMVm:CS, BSMVm:AS, or BSMVm:CM displayed a signifi-

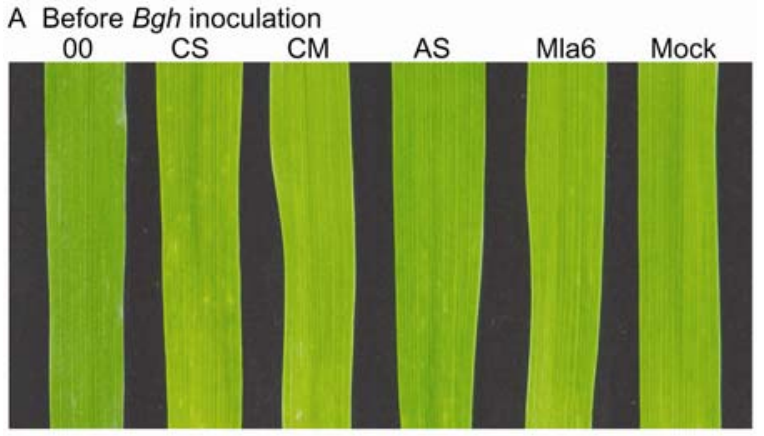

B Seven days after Bgh inoculation

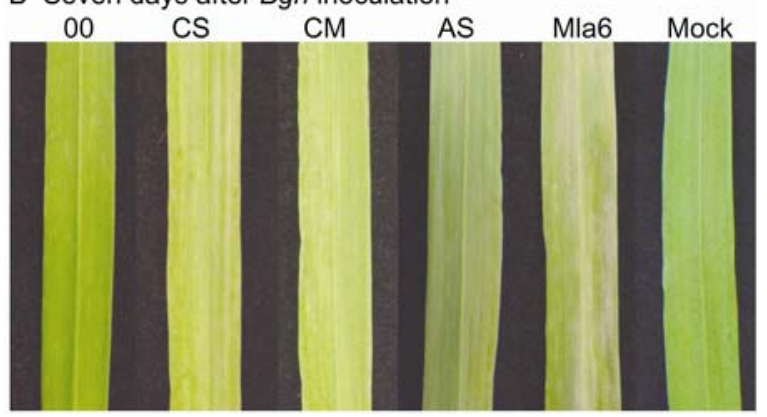

Fig. 3. Phenotypes of Barley stripe mosaic virus-induced gene silencing (BSMV-VIGS)-treated plants. C.I. 16151 plants infected with BSMVVIGS empty vector (BSMVm:00) and test constructs $\mathbf{A}$, before and $\mathbf{B}, 7$ days after B. graminis f. sp. hordei 5874 (AVRa6) inoculation. BSMVVIGS empty vector and constructs containing target gene fragments $H v C S, H v C M 1, H v A S a 2$, and Mla6 are abbreviated as 00, CS, CM, AS, and Mla6, respectively. Photographs were taken A, 9 days and B, 16 days post bombardment of BSMV-VIGS constructs.

Table 2. Blumeria graminis f. sp. hordei penetration efficiency (PE) in transient-induced gene silencing assay II

\begin{tabular}{|c|c|c|c|c|c|}
\hline \multirow[b]{2}{*}{ Construct } & \multicolumn{2}{|c|}{ Number of cells ${ }^{a}$} & \multirow[b]{2}{*}{$\mathbf{P E}^{\mathbf{d}}$} & \multicolumn{2}{|c|}{$P$ value $^{\text {b }}$} \\
\hline & Attacked $^{\mathrm{c}}$ & With haustoria & & Empty vector vs. others & hpMla6 vs. others \\
\hline pIPKTA30 & 426 & 30 & 6.69 & n.a. & $<0.0001$ \\
\hline hpAS + hpCM & 450 & 15 & 3.01 & 0.1338 & $<0.0001$ \\
\hline hpAS + hpCS & 396 & 15 & 3.42 & 0.1788 & $<0.0001$ \\
\hline $\mathrm{hpCM}+\mathrm{hpCS}$ & 540 & 21 & 3.90 & 0.3202 & $<0.0001$ \\
\hline hpMla6 & 864 & 453 & 52.43 & $<0.0001$ & n.a. \\
\hline hpMla6 + hpAS + hpCM & 930 & 570 & 61.39 & $<0.0001$ & 0.0012 \\
\hline hpMla6 + hpAS + hpCS & 1,062 & 672 & 63.14 & $<0.0001$ & 0.0004 \\
\hline hpMla6 + hpCM + hpCS & 1,953 & 1,200 & 61.41 & $<0.0001$ & 0.0017 \\
\hline
\end{tabular}

${ }^{a}$ Raw numbers indicate the combined total of three independent experiments.

${ }^{\text {b }} P$ values were obtained using a mixed linear model to test for a significant difference of the PE by the test constructs versus the empty vector negative control or the hpMla6 positive control. A $P$ value $<0.05$ indicates that the PEs are significantly different; n.a. $=$ not available.

c Attacked with B. graminis f. sp. hordei.

${ }^{\mathrm{d}} \mathrm{PE}$ is shown as the mean of the PE from three independent replications. 
cant difference in penetration efficiency from the BSMVm:00 empty vector control (Table 3). The susceptibility of BSMVm:CS treated plants was $24 \%$, on average, compared with $48 \%$ for BSMVm:Mla6-treated (positive control) plants. BSMVm:AS- and BSMVm:CM-infected plants displayed a lower susceptibility index of 13 and $15 \%$, respectively (Table 3 ). No colonization of $B$. graminis f. sp. hordei was detected after macroscopic observation (Fig. 3); therefore, we inferred that $B$. graminis f. sp. hordei can form haustoria and secondary hyphae but fail to propagate in the silenced plants. Finally, inspection of 7-dai BSMVm:CS-, BSMVm:AS-, or BSMVm:CM-treated plants by microscopy revealed that only elongated secondary hyphae were detected without sporulation (Fig. 4B), whereas abundant $B$. graminis $\mathrm{f}$. sp. hordei sporulation was observed 7 dai on BSMVm:Mla6 $R$-gene-silenced plants or the Manchuria non-virus-infected susceptible control (Fig. 4B). MLA6-mediated resistance normally halts further development of $B$. graminis f. sp. hordei after penetration, whereas the above results indicate that silencing genes encoding metabolic enzymes facilitate $B$. graminis f. sp. hordei penetration and secondary hyphae development, indicating that expression of these genes influences the rate of $B$. graminis f. sp. hordei development in Mla-mediated barley-powdery mildew interactions.

\section{Quantitative reverse-transcription polymerase chain} reaction of target gene $m$ RNA from VIGS-treated plants.

To confirm whether a specific candidate gene's mRNA had been targeted, quantitative reverse-transcription polymerase chain reaction (qRT-PCR) was performed. Second leaves of BSMV-treated plants were used for RT-PCR assays 7 dai with
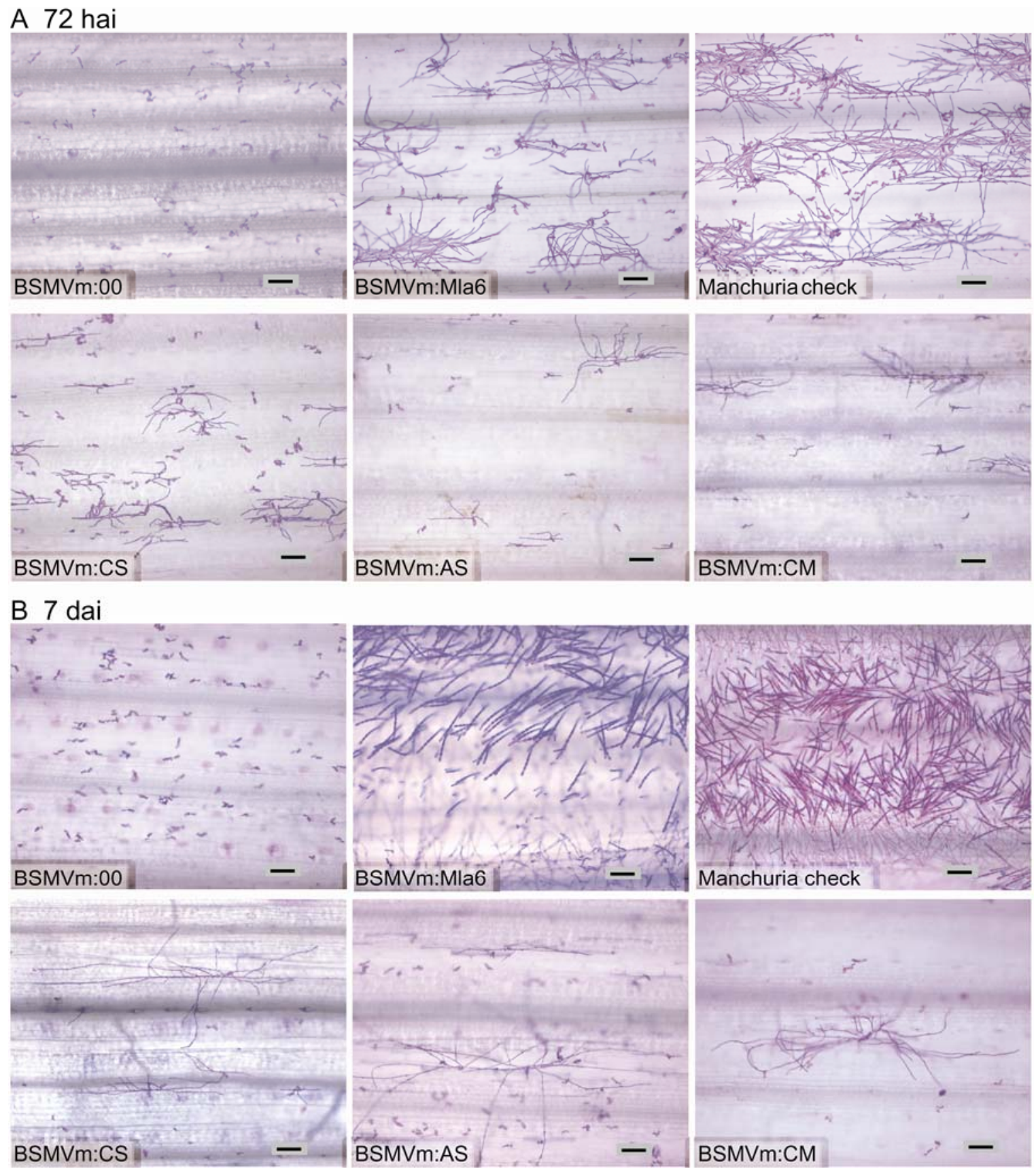

Fig. 4. Blumeria graminis f. sp. hordei infection structures in Barley stripe mosaic virus-induced gene silencing (BSMV-VIGS)-silenced and control barley leaves. C.I. 16151 (Mla6) plants infected with BSMV-VIGS constructs were inoculated with B. graminis f. sp. hordei isolate 5874 (AVRa6). Barley leaves were fixed at $\mathbf{A}, 72 \mathrm{~h}$ after inoculation (hai) and $\mathbf{B}, 7$ days after inoculation (dai). Manchuria barley was included as a susceptible inoculation control. BSMVVIGS constructs and Manchuria check are designated at the lower-left corner of each picture. The bars represent $100 \mu \mathrm{m}$ in length. 
B. graminis f. sp. hordei. Actin mRNA was used as an internal quantitative control for all samples. mRNA levels of $\mathrm{HvCS}$, $H v A S a 2, H v C M 1$, and Mla6 from plants treated with matching BSMV constructs decreased efficiently compared with mRNAs from BSMVm:00 controls (Fig. 5). For most silenced genes, there are no detectable amplicons at 25 and 30 cycles. However, amplicons could be detected at 35 PCR cycles, indicating that trace mRNA of the target genes was still present and silencing was not $100 \%$ efficient. This is consistent with the observed heterogeneous silencing pattern observed in BSMVm: PDS plants (Scofield et al. 2005). In order to test whether crosssilencing had occurred in BSMVm:CM- and BSMVm:AStreated plants, specific primers were designed to amplify the
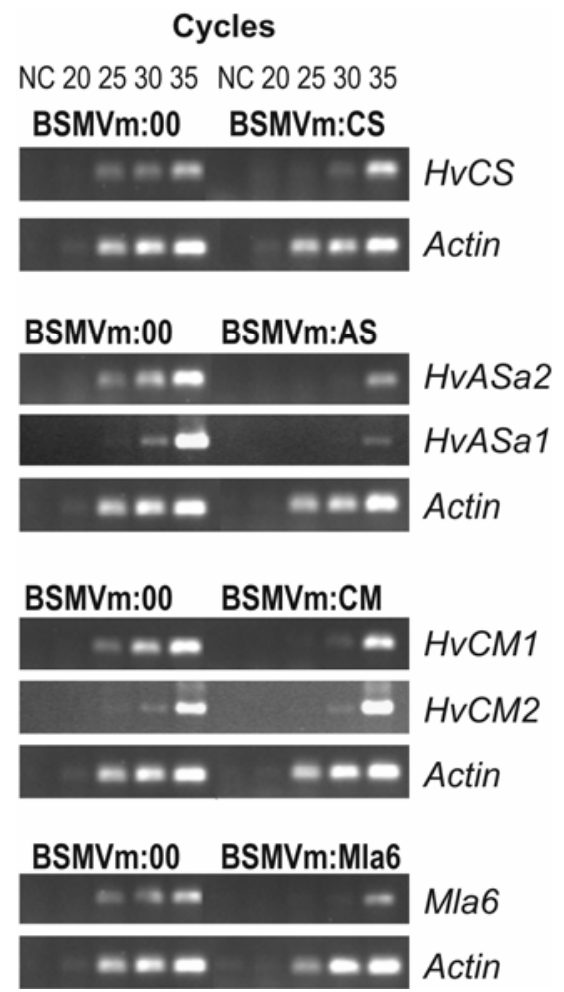

Fig. 5. Barley stripe mosaic virus-induced gene silencing (BSMV-VIGS)induced mRNA degradation of target transcripts. Degradation of target transcripts was assayed via quantitative reverse-transcription polymerase chain reaction of C.I. 16151 plants treated with BSMV-VIGS empty vector (BSMVm:00) compared with corresponding test constructs. Plants were inoculated with Blumeria graminis f. sp. hordei 9 days after attempted silencing. Tissue was harvested for RNA preparation $72 \mathrm{~h}$ after B. graminis f. sp. hordei inoculation. Gene-specific primers were used to amplify $H v C S$, $H v A S a 2, H v A S a 1, H v C M 1, H v C M 2$, and Mla6 transcripts. "NC" of each sample RNA represents the negative control without reverse transcription. Lanes designated 20,25, 30, and 35 represent amplification cycles performed for each sample. Actin transcripts were used as a quantitative control. nontargeted family members, $H v C M 2$ and $H v A S a l$. qRT-PCR performed with primers specific for $\mathrm{HvCM} 2$ showed no difference in mRNA levels from the controls, indicating a low probability of cross-silencing with $B$. graminis f. sp. hordeiinducible $H v C M 1$. However, decreased amplification of $\mathrm{HvASal}$ RNAs from the BSMVm:AS-silenced plants indicated that some cross-silencing had occurred (Fig. 5).

\section{$H v C S, H v C M 1$, and $H v A S a 2$ contribute \\ to mlo-mediated broad-spectrum resistance.}

The barley mlo gene, which encodes a seven-transmembrane protein (Devoto et al. 1999), is a negative defense regulator in barley-B. graminis f. sp. hordei interactions. Transient overexpression of Mlo in wild-type Mlo plants results in supersusceptibility (Kim et al. 2002). In contrast, mutant mlo derivatives mediate non-race-specific resistance early during pathogen penetration (Büschges et al. 1997; Consonni et al. 2006; Freialdenhoven et al. 1996; Wolter et al. 1993).

Our previous TIGS and VIGS results indicate that silencing genes in secondary metabolism influences fungal penetration. We reasoned that, if defense components derived from Tyr/Phe or Trp synthetic pathways are involved in penetration defense, overexpression of the three genes would quantitatively decrease penetration efficiency. A single-cell transient overexpression assay was performed to investigate whether $\mathrm{HvCS}, \mathrm{HvASa} 2$, and $H v C M 1$ could lessen $M l o$-mediated susceptibility to $B$. graminis f. sp. hordei. Expression constructs containing the open reading frames of $H v C S, H v A S a 2$, or $H v C M 1$, each preceded by the ubiquitin promoter, were tested for function in $m l o-5 \mathrm{BC}_{7}$ Ingrid seedlings by co-bombardment with the V26UMUG vector, which encodes both the GUS and Mlo genes (Shirasu et al. 1999a). In this assay, GUS-marked epidermal cells were rendered susceptible to B. graminis f. sp. hordei due to the presence of wild-type Mlo, contained within the V26UMUG vector, whereas neighboring nontransformed cells retained broad-spectrum mlo-5 resistance (Halterman and Wise 2004).

Results of three independent overexpression experiments indicated that the three genes had significantly decreased penetration efficiency compared with the V26UMUG (GUS-Mlo) control (Table 4). The average B. graminis f. sp. hordei penetration efficiency in leaves bombarded with the GUS-Mlo reporter plasmid, V26UMUG, was $80.44 \%$. Bombardment with $H v C S$ decreased the penetration efficiency by $26.5 \%$ on average compared with the control, with a $P$ value of 0.0004 . Transformation with $H v C M 1$ and $H v A S a 2$ reduced B. graminis f. sp. hordei penetration efficiency by 14.7 and $12.0 \%$ on average, respectively. Including both $\mathrm{HvCM} 1$ and $\mathrm{HvASa} 2$ in the bombardment had effects in reducing $B$. graminis f. sp. horde $i$ penetration efficiency equivalent to overexpressing $\mathrm{HvCMI}$ alone, suggesting that $i$ ) there is no additive effect of combining $H v C M 1$ and $H v A S a 2$ expression and ii) $H v C S$ appears to have a greater effect than $H v C M 1$ or $H v A S a 2$ on $B$. graminis f. sp. hordei penetration efficiency.

Table 3. Blumeria graminis f. sp. hordei penetration efficiency (PE) in C.I. 16151 (Mla6) treated with Barley stripe mosaic virus (BSMV) constructs

\begin{tabular}{|c|c|c|c|c|c|}
\hline \multirow[b]{2}{*}{ Treatment } & \multicolumn{2}{|c|}{ Number of cells ${ }^{a}$} & \multirow[b]{2}{*}{$\mathbf{P E} \mathbf{E}^{\mathrm{d}}$} & \multicolumn{2}{|c|}{$P$ value $^{b}$} \\
\hline & Attacked $^{c}$ & With haustoria & & BSMVm:00 vs. others & BSMVm:Mla6 vs. others \\
\hline BSMVm:00 & 1,971 & 54 & 3.15 & n.a. & $<0.0001$ \\
\hline BSMVm:AS & 1,791 & 219 & 13.04 & 0.0083 & $<0.0001$ \\
\hline BSMVm:CM & 1,281 & 198 & 15.45 & 0.0024 & $<0.0001$ \\
\hline BSMVm:CS & 2,475 & 609 & 24.03 & $<0.0001$ & $<0.0001$ \\
\hline BSMVm:Mla6 & 1,707 & 861 & 48.03 & $<0.0001$ & n.a. \\
\hline
\end{tabular}

${ }^{a}$ Raw numbers indicate the combined total of three independent experiments.

${ }^{\mathrm{b}} P$ values were obtained using a mixed linear model to test for a significant difference of the PE by comparing the test BSMV constructs versus the BSMVm:00 empty vector or the BSMVm:Mla6 positive control. A $P$ value $<0.05$ indicates that the PEs are significantly different; n.a. $=$ not available.

${ }^{c}$ Attacked with B. graminis f. sp. hordei.

${ }^{\mathrm{d}} \mathrm{PE}$ is shown as the mean of the PE from three independent replications. 
BSMV-VIGS interferes

with mlo-mediated resistance to powdery mildew.

To investigate whether silencing the three genes compromises mlo-mediated broad-spectrum resistance, the BSMVm:00, BSMVm:CS, BSMVm:AS, and BSMVm:CM constructs were tested on the penetration-resistant line $m l o-5 \mathrm{BC}_{7}$ Ingrid. Interestingly, sporulation of B. graminis f. sp. hordei was observed on plants at 7 dai treated with both BSMV empty vector and BSMV constructs containing the three candidate genes, indicating that BSMV itself interferes with mlo-mediated resistance to powdery mildew (Supplementary Fig. 1). The mlomediated resistance requires vesicle transport and a membrane fusion event (Bhat et al. 2005; Collins et al. 2003). Some plant virus-encoded cell-to-cell movement proteins are bound to the endoplasmic reticulum (ER) and are involved in vesicle transport (Ploubidou and Way 2001; Verchot-Lubicz et al. 2007). For example, Potato virus $X$ encodes TGBp2 which, upon infection, induces ER-derived granular-type vesicles that are critical for the virus movement (Verchot-Lubicz et al. 2007). BSMV TGB1, TGB2, and TGB3 proteins are required for cellto-cell movement (Lawrence and Jackson 2001b). Subcellular localization revealed that TGB1 is associated with ER and TGB2 is associated with membrane and cell wall fractions, suggesting that BSMV cell-to-cell movement requires viral protein cytoplasmic membrane association (Lawrence and Jackson 2001a,b). We hypothesize that BSMV infection changes the host membrane system and, thus, interferes with mlo-mediated resistance, resulting in a susceptible phenotype in BSMV-treated plants.

\section{DISCUSSION}

\section{Secondary metabolic enzymes contribute to penetration resistance.}

Previously, we showed that several genes encoding secondary metabolic enzymes are nonspecifically induced in both compatible and incompatible interactions before B. graminis f. sp. hordei haustorium formation and then differentially expressed after penetration (Caldo et al. 2004, 2006). Our functional analysis in this study demonstrated that genes at pivotal branch points are involved in penetration resistance, which is one of the major components in basal defense. TIGS results demonstrated that, in $M l a$-compromised cells, impairment of $H v C S$ and $H v C M 1$ functions to increase $B$. graminis f. sp. hordei penetration efficiency, indicating that these enzymes and their downstream components contribute to host defense. Overexpression of $\mathrm{HvCS}, \mathrm{HvASa2}$, and $H v C M 1$ in the presence of MLO, a negative regulator of basal defense, significantly decreased the penetration efficiency compared with overexpression of Mlo alone. The mlo mutants confer resistance during $B$. graminis f. sp. hordei penetration, characterized as early and large papillae formation. It is believed that $B$. graminis $\mathrm{f}$. sp. hordei recruits MLO as a virulence target to suppress host basal defense (Büschges et al. 1997; Devoto et al. 1999). Bhat and associates (2005) showed that MLO protein accumulates beneath fungal appressoria upon $B$. graminis $\mathrm{f}$. $\mathrm{sp}$. hordei penetration and the association between MLO and its interacting calmodulin is coincident with successful invasion of $B$. graminis f. sp. hordei. The decreased penetration efficiency in Mlo-transformed cells via overexpression of $\mathrm{HvCS}, \mathrm{HvASa2}$, and $H v C M 1$ indicates that these metabolic enzymes contribute to host penetration resistance.

In this study, silencing and overexpression of $\mathrm{HvCS}$ showed prominent effects on penetration resistance. We should note that abolishment of CS function may dramatically disturb plant metabolism, resulting in some pleiotropic effects. At this time, we cannot differentiate between effects on penetration resistance in $H v C S$-silenced plants from possible pleiotropic effects on defense due to disturbance in aromatic amino acid synthesis and the resulting metabolic sink. However, $\mathrm{HvASa} 2$ and $H v C M 1$ are $B$. graminis f. sp. hordei inducible, while genes encoding their isoenzymes HvASa1 and HvCM2 mediate steady-state secondary metabolic functions. In this scenario, even if the functions of $\mathrm{HvASa} 2$ or $\mathrm{HvCM}$ l or both are disabled, steady-state secondary metabolic functions could still be operating through HvASa1 and HvCM2. qRT-PCR results showed a low probability of cross-silencing between housekeeping gene $H v C M 2$ and $B$. graminis f. sp. hordei-inducible $H v C M 1$ (Fig. 5). However, decreased amplification of HvASal RNAs from the BSMVm:AS-silenced plants indicated that crosssilencing had occurred. It is unclear whether cross-silencing of $H v A S a l$ would have an effect on the penetration phenotype, because time-course GeneChip expression profiles displayed a clear downregulation of $\mathrm{HvASal}$ (Barley1_11179), in contrast to the significant induction of $H v A S a 2$ (Barley1_48443). It is possible that silencing $H v A S \alpha$ subunit expression affects the metabolic flow in Trp biosynthetic pathway and interferes with basic cell functions, resulting in a decreased defense response.

Host resistance to fungal pathogens can act at either the invasion or post-invasion stage. Gene-for-gene interactions usually function during post invasion. Though, in plant-biotrophic pathogen interactions, it is still not clear how AVR effectors are recognized by $\mathrm{R}$ proteins, it is widely believed that either direct or indirect recognition between AVR and R proteins occurs inside the host cell (Catanzariti et al. 2007; Ridout et al. 2006; van den Burg et al. 2006). The subsequent signaling cascade often results in a hypersensitive response (HR), which halts further development of the pathogen. mlo-Mediated broadspectrum resistance is categorized under invasion defense, in which haustoria or HR are not observed (Peterhansel et al. 1997). Recent studies on penetration resistance reveal that it is highly associated with transportation of vesicles and other toxic components at the pathogen-attacked sites (Bhat et al. 2005; Collins et al. 2003; Lipka et al. 2005; Stein et al. 2006).

Arabidopsis does not support the growth and asexual reproduction of $B$. graminis f. sp. hordei. Conidia will germinate and form appressoria but the majority will not penetrate the epidermal cell wall and papillae. A series of mutations belonging to three complementation groups (pen1, pen2, and pen3) allow increased penetration by B. graminis f. sp. hordei. PEN1 encodes a syntaxin (SYP121) (Collins et al. 2003), PEN2 encodes a glycosyl hydrolase (Lipka et al. 2005), and PEN3 encodes the putative ATP-binding cassette (ABC) transporter PDR8 (Stein et al. 2006). Current hypotheses envisage that

Table 4. Blumeria graminis f. sp. hordei penetration efficiency (PE) with overexpression of $\mathrm{HvCS} / \mathrm{HvCM} 1 / \mathrm{HvASa} 2$ and $\beta$-glucuronidase (GUS)mildew resistance locus $o$ (Mlo) in mlo-5 plants

\begin{tabular}{lcccc}
\hline & \multicolumn{2}{c}{ Number of cells $^{\mathbf{a}}$} & & \\
\cline { 2 - 3 } Construct & Attacked $^{\mathbf{b}}$ & With haustoria $^{\text {N }}$ & PE $^{\mathbf{c}}$ & $\boldsymbol{P}_{\text {value }}$ \\
\hline GUS-Mlo $^{\mathrm{e}}$ & 772 & 596 & 80.44 & n.a. \\
GUS-Mlo + AS & 513 & 360 & 68.47 & 0.0415 \\
GUS-Mlo + CM & 764 & 488 & 65.67 & 0.0106 \\
GUS-Mlo + CS & 898 & 490 & 53.92 & 0.0004 \\
GUS-Mlo + CM + AS & 284 & 170 & 66.26 & 0.0128 \\
\hline
\end{tabular}

${ }^{a}$ Raw numbers indicate the combined total of three independent experiments.

${ }^{\mathrm{b}}$ Attacked with B. graminis f. sp. hordei.

${ }^{c} \mathrm{PE}$ is shown as the mean of the PE from three independent replications.

${ }^{\mathrm{d}} P$ values (GUS-Mlo vs. others) were obtained using a mixed linear model to test for a significant difference of the PE by comparing the test constructs versus the GUS-Mlo control. A $P$ value $<0.05$ indicates that the PEs are significantly different; n.a. = not available.

${ }^{\mathrm{e}}$ Control GUS-Mlo construct was co-bombarded with the overexpression empty vector to obtain a mole equivalence with other treatments. 
antimicrobial components produced by the PEN2 glycosyl hydrolase are transported to pathogen-attacked sites by the PEN3 ABC transporter (Stein et al. 2006). It is possible that some antimicrobial products derived from the secondary metabolic pathway are one of the targets for PEN3, and decreasing of certain antimicrobial compounds weakens penetration resistance. These antimicrobial products could be phenylpropanoid or indole derivatives; data presented in this report demonstrates that impairment of the Tyr/Phe biosynthetic pathway increased $B$. graminis f. sp. hordei haustorial formation, an indicator of penetration efficiency. One candidate from the phenylpropanoid pathway is p-coumaroyl-hydroxyagmatine (p-CHA), which attains levels 25-fold higher in mlo-3 and mlo-5 than in wild-type Mlo plants (von Ropenack et al. 1998). Von Ropenack and colleagues (1998) showed that p-CHA has antimicrobial activity in vitro and in vivo, which reduced $B$. graminis f. sp. hordei appressoria and haustoria formation. In this scenario, it is possible that p-CHA at the invasion sites is toxic to $B$. graminis f. sp. hordei and contributes to penetration resistance.

Silencing genes in the aromatic amino acid synthetic pathway will affect more than one single metabolic product and its corresponding penetration resistance pathway. Lignin, which serves as a mechanical barrier to pathogens, may affect penetration efficiency. Cell-wall-bound phenylpropanoid derivatives also contribute to penetration resistance. In mlo plants, cell wall apposition papilla is usually larger and forms earlier than in wild-type Mlo plants (Collins et al. 2003). Cell-wallbound phenolics around papilla in mlo plants display resistance to saponification $2 \mathrm{~h}$ earlier than in corresponding Mlo wild-type plants (von Ropenack et al. 1998), indicating that early papilla formation is important for invasion resistance.

\section{Virus-induced silencing of metabolic genes interferes with the rate of $B$. graminis $\mathbf{f}$. sp. hordei development in Mla-mediated barley-powdery mildew interactions.}

Penetration resistance is a complex and dynamic process, involving multiple positive and negative factors (Bhat et al. 2005; Collins et al. 2003; Lipka et al. 2005; Stein et al. 2006). BSMV-VIGS of $H v C S, H v A S a 2$, and $H v C M 1$ in C.I. 16151 (Mla6) plants displayed fully developed B. graminis f. sp. hordei haustoria and ESH, but without sporulation. However, in typical Mla6-mediated resistance, developing haustoria are terminated and ESH are not observed (Halterman et al. 2001; Wise and Ellingboe 1983). These results provide for a temporal division between the formation of haustoria or secondary hyphae and Mla-mediated resistance. Either early establishment of $B$. graminis f. sp. hordei infection inside of the host cells or delayed Mla resistance will allow B. graminis f. sp. hordei enough time to form haustoria and secondary hyphae before the manifestation of HR. In the first scenario, the weakened penetration defense in plants silenced for $H v C S, H v C M 1$, or $H v A S a 2$ may facilitate rapid $B$. graminis f. sp. hordei penetration and enough lag time to establish its haustoria and secondary hyphae before Mla-triggered HR. Alternatively, silencing the three genes interferes with Mla-mediated resistance, resulting in a delayed defense response. Shen and associates (2007) demonstrated that barley MLA10 regulates basal defense through WRKY transcription factors. It was shown that the recognition between MLA10 and its corresponding pathogen effector, $A V R_{a 10}$, induces the association between MLA10 and WRKY1/2, blocking WRKY function, resulting in derepression of basal defenses. In this scenario, Mla-mediated resistance still requires a set of basal defense gene functions. Further research is necessary to determine the diversity of antimicrobial products that function in the barley-powdery mildew defense response.

\section{MATERIALS AND METHODS}

\section{Plant materials and fungal isolates.}

Seven-day-old seedlings of C.I. 16151 (Mla6) (Moseman 1972) and $m l o-5 \mathrm{BC}_{7}$ Ingrid were used for the single-cell transient assays and VIGS assays. Virus-infected barley was maintained in a growth chamber (Percival Scientific, Perry, IA, U.S.A.) at $24^{\circ} \mathrm{C}$ with $16 \mathrm{~h}$ of light $\left(550 \mu \mathrm{mol} / \mathrm{m}^{2} / \mathrm{s}\right)$ and $8 \mathrm{~h}$ of darkness at $20^{\circ} \mathrm{C}$. B. graminis f. sp. hordei isolate $5874\left(A V R_{a l}\right.$ and $A V R_{a 6}$ ) was propagated on Hordeum vulgare cv. Manchuria at $18^{\circ} \mathrm{C}(16 \mathrm{~h}$ of light and $8 \mathrm{~h}$ of darkness).

\section{$H v C S, H v A S a 2$, and $H v C M 1$ full-length cDNA cloning.}

The $H v C M 1$ full-length cDNA clone was obtained from CUGI (Clemson University Genomics Institute) EST $\mathrm{Hv}_{-}$ CEb0009G14. Full-length cDNAs of $H v C S$ and $H v A S a 2$ were obtained from $5^{\prime}$ rapid amplification of cDNA ends (RACE) using the GeneRace kit (Invitrogen, Carlsbad, CA, U.S.A.). $H v C S$ and $H v A S a 2$ nucleotide sequences were extended into the $5^{\prime}$ untranslated region by three rounds of PCR with the nested primer (provided by the manufacturer) and genespecific primers, listed in Supplementary Table 1. Sequence information from $5^{\prime}$ RACE was used to design gene-specific 5' primers, which were used to amplify full-length cDNAs of $H v C S$ and $H v A S a 2$ by SuperScript One-Step RT-PCR with the Plantinum Taq System. RT-PCR products were ligated into the pCR2.1-TOPO vector as TOPO-CS and TOPO-AS.

\section{Plasmid construction.}

Primers used for TIGS and VIGS are listed in Supplementary Table 2. Barley gene fragments were cloned into the hairpin vector pIPKTA30 for TIGS assays (Douchkov et al. 2005). The BSMV-VIGS vector (Scofield et al. 2005) was modified for biolistic transfer (Meng et al. 2009). For VIGS assays, $H v C S, H v A S a 2$, and $H v C M 1$ gene fragments were cloned into the BSMVm: $\gamma$ vector as BSMVm:CS, BSMVm:AS, and BSMVm:CM, respectively. The UbiNos_2-3 vector, which was modified from a UbiNos vector (Shirasu et al. 1999a) by inserting the multiple cloning site (5'-AGCTTCTGCAGCCC GGGGGATCCGAGCTCG-3') between HindIII and EcoRV, was used to express $H v C S, H v A S a 2$, and $H v C M 1$. Open reading frames of $H v C S, H v C M 1$, and $H v A S a 2$ were cloned into UbiNos_2-3.

\section{Single-cell transient assays.}

Bombardment of barley leaves was carried out via BioRad (Hercules, CA, U.S.A.) PDS-1000/He Biolistic transfer system. Gold particles (BioRad) were coated as described (Douchkov et al. 2005). For TIGS assays, 7-day-old barley seedlings were bombarded at 650 pounds per square inch using a hepta adaptor. Seedlings were then grown in the greenhouse for 6 days before inoculation. Leaves were cut and placed randomly on $1 \%$ Phytoagar (Ducheva, Haarlem, The Netherlands) in a 22.5-by-22.5$\mathrm{cm}$ Nunc plate for inoculation. For overexpression, detached barley leaves were prepared for biolistic transfer as described previously (Halterman and Wise 2004; Halterman et al. 2001). The inoculated leaves were incubated at $18^{\circ} \mathrm{C}(16 \mathrm{~h}$ of light and $8 \mathrm{~h}$ of darkness) for 5 days. Leaves then were immersed in a GUS solution (0.1 $\mathrm{M} \mathrm{Na}_{2} \mathrm{HPO}_{4} / \mathrm{NaH}_{2} \mathrm{PO}_{4}, \mathrm{pH} 7.0 ; 10 \mathrm{mM} \mathrm{Na}-$ EDTA; $5 \mathrm{mM}$ potassium hexacyanoferrat [II] and potassium hexacyanoferrat [III]; 5-bromo-4-chloro-3-indoxyl-b-d-glucuronic acid at $1 \mathrm{mg} / \mathrm{ml}$; cyclohexylammonium salt; $0.1 \%$ (vol/vol) Triton X-100; $20 \%$ [vol/vol] methanol) at $37^{\circ} \mathrm{C}$ overnight and stained with Coomassie blue $(0.3 \%$ [wt/vol] Coomassie blue and 7.5 and $30 \%$ [vol/vol] methanol) as described (Halterman and Wise 2004; Halterman et al. 2001). Scoring for susceptibility was performed under light microcopy 
by counting the number of GUS cells with haustoria to the total GUS cells with attached $B$. graminis $\mathrm{f}$. $\mathrm{sp}$. hordei conidiospores.

\section{VIGS.}

Seven-day-old seedlings of barley cv. C.I. 16151 were infected with BSMV via co-bombardment of BSMVm: $\alpha$, BSMVm: $\beta$, and modified BSMVm: $\gamma$ containing the designated target gene fragment. Biolistic transfer procedure was identical to that in TIGS assays described previously. The seedlings were then placed in the VIGS growth chamber (Percival Scientific) for silencing 9 days prior to $B$. graminis f. sp. hordei inoculation. Plant-B. graminis f. sp. hordei interaction phenotypes were scored 7 to 9 dai. For microscopic observation, virusinfected leaves were cut and placed randomly on $1 \%$ Phytoagar (Ducheva) in a 22-by-22-cm Nunc plate for inoculation. The inoculated leaves were incubated at $18^{\circ} \mathrm{C}(16 \mathrm{~h}$ of light and $8 \mathrm{~h}$ of darkness) for $72 \mathrm{~h}$. Leaves were fixed in a ethanol/ acetic acid ( $3: 1, \mathrm{vol} / \mathrm{vol})$ solution overnight and subsequently washed with deionized water twice and stained with Coomassie blue $(0.3 \%$ [wt/vol] Coomassie blue and 7.5 and $30 \%$ [vol/vol] methanol) as described (Halterman and Wise 2004; Halterman et al. 2001). Barley-B. graminis f. sp. hordei interaction phenotypes were scored by light microscopy.

\section{qRT-PCR of BSMV-VIGS-treated plants.}

Second leaves from each BSMV-VIGS-treated plant that displayed a typical mosaic virus infection symptom were sampled for RT-PCR. Barley total RNA was isolated using a hot $\left(60^{\circ} \mathrm{C}\right)$ phenol/guanidine thiocyanate method as described previously (Caldo et al. 2004) and treated with DNase I. Two $\mu \mathrm{g}$ of RNA was transcribed into cDNA with a oligodT primer by SuperScript III reverse transcriptase (Invitrogen). First-strand cDNAs were used as templates for amplifying target gene fragments at cycling conditions of $92^{\circ} \mathrm{C}$ for $20 \mathrm{~s}, 58^{\circ} \mathrm{C}$ for 20 $\mathrm{s}$, and $68^{\circ} \mathrm{C}$ for $15 \mathrm{~s}$ with $20,25,30,35$, and 40 cycles. Actin was used as internal constitutive expression control for cDNA quantitative normalization.

\section{Data collection and statistical analysis.}

In single-cell transient assays, scoring for susceptibility was performed under light microcopy by counting the number of GUS cells with haustoria compared with the total GUS cells attacked by $B$. graminis f. sp. hordei, as evidenced by an attached conidiospore. For each experiment, eight leaves per treatment were counted. At least three independent replicates were performed. The ratio of susceptible cells to the total attacked GUS cells was calculated per treatment per experiment for statistical analysis. A completely randomized design was applied to each experiment. $P$ values were calculated with a mixed linear model $\left(y_{i j}=\tau_{i}+\eta_{j}+\varepsilon_{i j}\right.$, where $y_{i j}$ is the penetration efficiency for the $(i)$ th TIGS treatment in the $(j)$ th replicate, $\tau_{i}$ is the fixed effect of $(i)$ th treatment with TIGS hairpin constructs, $\eta_{j}$ is the random effect of $(j)$ th replicate, and $\varepsilon_{i j}$ is the error residual) via SAS (Statistical Analysis Software; SAS Institute Inc., Cary, NC, U.S.A.). In VIGS assays, BMSV-VIGS-treated barley plants displayed a mosaic silencing phenotype in restricted regions, which is consistent with BSMV movement (Lawrence and Jackson 2001a,b). Therefore, a counting unit was defined as a 5-mm-long section between two veins. Per leaf, regions with the most susceptible cells were selected as counting units for which conidiospores with fully developed appressoria were counted. Susceptibility was calculated as the ratio of conidiospores with haustoria or secondary hyphae to the total conidiospores per treatment per experiment. Three independent experiments were performed where at least 600 conidiospores were counted per treatment. A completely randomized design was applied to each experiment. $P$ values were calculated with a mixed linear model via SAS as above, except substituting BSMV-VIGS in the place of TIGS in the formula.

\section{ACKNOWLEDGMENTS}

We thank S. Whitham and C. Zhang for critical comments on the manuscript; P. Schweizer for providing RNAi cloning vectors pIPKTA30, pIPKTA38, and advice on the TIGS assay; and S. Scofield for BSMV cDNAs. Research supported by National Science Foundation Plant Genome grant 0500461 and United States Department of Agriculture-Agricultural Research Service CRIS Project 3625-21000-049-00D. Mention of trade names or commercial products is solely for the purpose of providing specific information and does not imply recommendation or endorsement by the United States Department of Agriculture.

\section{LITERATURE CITED}

Aist, J. R., and Bushnell, W. R. 1991. Invasion of plant hosts by powdery mildew fungi and cellular mechanism of resistance. Pages 321-345 in: The Fungal Spore and Disease Initiation in Plants and Animals. G. T Cole and H. C. Hoch, eds. Plenum Press, New York.

Aist, J. R., Gold, R. E., Bayles, C. J., Morrison, G. H., Chandra, S., and Israel, H. W. 1988. Evidence that molecular components of papillae may be involved in ml-o resistance to barley powdery mildew. Physiol. Mol. Plant Pathol. 33:17-32.

Bhat, R. A., Miklis, M., Schmelzer, E., Schulze-Lefert, P., and Panstruga, R. 2005. Recruitment and interaction dynamics of plant penetration resistance components in a plasma membrane microdomain. Proc. Natl. Acad. Sci. U.S.A. 102:3135-3140.

Bieri, S., Mauch, S., Shen, Q.H., Peart, J., Devoto, A., Casais, C., Ceron, F., Schulze, S., Steinbiss, H. H., Shirasu, K., and Schulze-Lefert, P 2004. RAR1 positively controls steady state levels of barley MLA resistance proteins and enables sufficient MLA6 accumulation for effective resistance. Plant Cell 16:3480-3495.

Bohlmann, J., Lins, T., Martin, W., and Eilert, U. 1996. Anthranilate synthase from Ruta graveolens (Duplicated AS[alpha] genes encode tryptophan-sensitive and tryptophan-insensitive isoenzymes specific to amino acid and alkaloid biosynthesis). Plant Physiol. 111:507-514.

Boyd, L. A., Smith, P. H., Foster, E. M., and Brown, J. K. M. 1995. The effects of allelic variation at the Mla resistance locus in barley on the early development of Erysiphe graminis f. sp. hordei and host responses. Plant J. 7:959-968.

Burhenne, K., Kristensen, B. K., and Rasmussen, S. K. 2003. A new class of N-hydroxycinnamoyltransferases. Purification, cloning and expression of a barley agmatine coumaroyltransferase (EC 2.3.1.64). J. Biol. Chem. 278:13919-13927.

Büschges, R., Hollricher, K., Panstruga, R., Simons, G., Wolter, M., Frijters, A., van Daelen, R., van der Lee, T., Diergaarde, P., Groenendijk, J., Topsch, S., Vos, P., Salamini, F., and Schulze-Lefert, P. 1997. The barley Mlo gene: A novel control element of plant pathogen resistance. Cell 88:695-705.

Caldo, R. A., Nettleton, D., and Wise, R. P. 2004. Interaction-dependent gene expression in Mla-specified response to barley powdery mildew. Plant Cell 16:2514-2528.

Caldo, R. A., Nettleton, D., Peng, J., and Wise, R. P. 2006. Stage-specific suppression of basal defense discriminates barley plants containing fastand delayed-acting Mla powdery mildew resistance alleles. Mol. PlantMicrobe Interact. 19:939-947.

Catanzariti, A.-M., Dodds, P. N., and Ellis, J. G. 2007. Avirulence proteins from haustoria-forming pathogens. FEMS (Fed. Eur. Microbiol. Soc.) Microbiol. Lett. 269:181-188.

Collins, N. C., Thordal-Christensen, H., Lipka, V., Bau, S., Kombrink, E., Qiu, J.-L., Huckelhoven, R., Stein, M., Freialdenhoven, A., Somerville, S. C., and Schulze-Lefert, P. 2003. SNARE-protein-mediated disease resistance at the plant cell wall. Nature 425:973-977.

Consonni, C., Humphry, M. E., Hartmann, H. A., Livaja, M., Durner, J., Westphal, L., Vogel, J., Lipka, V., Kemmerling, B., Schulze-Lefert, P., Somerville, S. C., and Panstruga, R. 2006. Conserved requirement for a plant host cell protein in powdery mildew pathogenesis. Nat. Genet. 38:716-720.

D’Amato, T. A., Ganson, R. J., Gaines, C. G., and Jensen, R. A. 1984. Subcellular localization of chorismate-mutase isoenzymes in protoplasts from mesophyll and suspension-cultured cells of Nicotiana silvestris. Planta 162:104-108.

Devoto, A., Piffanelli, P., Nilsson, I., Wallin, E., Panstruga, R., von Heijne, G., and Schulze-Lefert, P. 1999. Topology, subcellular localization, and sequence diversity of the Mlo family in plants. J. Biol. Chem. 274:34993-35004. 
Dixon, R. A. 2001. Natural products and plant disease resistance. Nature 411:843-847.

Douchkov, D., Nowara, D., Zierold, U., and Schweizer, P. 2005. A highthroughput gene-silencing system for the functional assessment of defense-related genes in barley epidermal cells. Mol. Plant-Microbe Interact. 18:755-761.

Eberhard, J., Ehrler, T. T., Epple, P., Felix, G., Raesecke, H.-R., Amrhein, N., and Schmid, J. 1996. Cytosolic and plastidic chorismate mutase isozymes from Arabidopsis thaliana: Molecular characterization and enzymatic properties. Plant J. 10:815-821.

Ellingboe, A. H. 1972. Genetics and physiology of primary infection by Erysiphe graminis f. sp. hordei. Phytopathology 62:401-406.

Ferrari, S., Galletti, R., Denoux, C., De Lorenzo, G., Ausubel, F. M., and Dewdney, J. 2007. Resistance to Botrytis cinerea induced in Arabidopsis by elicitors is independent of salicylic acid, ethylene, or jasmonate signaling but requires PHYTOALEXIN DEFICIENT3. Plant Physiol. 144:367-379.

Flor, H. 1971. Current status of the gene-for-gene concept. Annu. Rev. Phytopathol. 9:275-296.

Freialdenhoven, A., Scherag, B., Hollricher, K., Collinge, D. B., ThordalChristensen, H., and Schulze-Lefert, P. 1994. Nar-1 and Nar-2, two loci required for Mla12-specified race-specific resistance to powdery mildew in barley. Plant Cell 6:983-994.

Freialdenhoven, A., Peterhansel, C., Kurth, J., Kreuzaler, F., and SchulzeLefert, P. 1996. Identification of genes required for the function of nonrace-specific mlo resistance to powdery mildew in barley. Plant Cell 8:5-14.

Gilchrist, D. G., Woodin, T. S., Johnson, M. L., and Kosuge, T. 1972. Regulation of aromatic amino acid biosynthesis in higher plants: I. Evidence for a regulatory form of chorismate mutase in etiolated mung bean seedlings. Plant Physiol. 49:52-57.

Glazebrook, J., and Ausubel, F. M. 1994. Isolation of phytoalexin-deficient mutants of Arabidopsis thaliana and characterization of their interactions with bacterial pathogens. Proc. Natl. Acad. Sci. U.S.A. 91:8955-8959.

Halterman, D., and Wise, R. P. 2004. A single-amino acid substitution in the sixth leucine-rich repeat of barley MLA6 and MLA13 alleviates dependence on RAR1 for disease resistance signaling. Plant J. 38:215-226.

Halterman, D., Zhou, F., Wei, F., Wise, R. P., and Schulze-Lefert, P. 2001. The MLA6 coiled-coil, NBS-LRR protein confers AvrMla6-dependent resistance specificity to Blumeria graminis f. sp. hordei in barley and wheat. Plant J. 25:335-348.

Hein, I., Barciszewska-Pacak, M., Hrubikova, K., Williamson, S., Dinesen, M., Soenderby, I. E., Sundar, S., Jarmolowski, A., Shirasu, K., and Lacomme, C. 2005. Virus-induced gene silencing-based functional characterization of genes associated with powdery mildew resistance in barley. Plant Physiol. 138:2155-2164.

Jones, D. A., and Takemoto, D. 2004. Plant innate immunity-direct and indirect recognition of general and specific pathogen-associated molecules. Curr. Opin. Immunol. 16:48-62.

Jones, J. D. G., and Dangl, J. L. 2006. The plant immune system. Nature 444:323-329

Jørgensen, J. H. 1994. Genetics of powdery mildew resistance in barley. Crit. Rev. Plant Sci. 13:97-119.

Kim, M. C., Panstruga, R., Elliott, C., Muller, J., Devoto, A., Yoon, H. W., Park, H. C., Cho, M. J., and Schulze-Lefert, P. 2002. Calmodulin interacts with MLO protein to regulate defence against mildew in barley. Nature 416:447-451.

Kuroki, G., and Conn, E. E. 1988. Increased chorismate mutase levels as a response to wounding in Solanum tuberosum L. tubers. Plant Physiol. 86:895-898

Lawrence, D. M., and Jackson, A. O. 2001a. Requirements for cell-to-cell movement of Barley stripe mosaic virus in monocot and dicot hosts. Mol. Plant Pathol. 2:65-75.

Lawrence, D. M., and Jackson, A. O. 2001b. Interactions of the TGB1 protein during cell-to-cell movement of Barley stripe mosaic virus. J. Virol. 75:8712-8723.

Lipka, V., Dittgen, J., Bednarek, P., Bhat, R., Wiermer, M., Stein, M., Landtag, J., Brandt, W., Rosahl, S., Scheel, D., Llorente, F., Molina, A., Parker, J., Somerville, S., and Schulze-Lefert, P. 2005. Pre- and postinvasion defenses both contribute to nonhost resistance in Arabidopsis. Science 310:1180-1183.

Matsukawa, T., Ishihara, A., and Iwamura, H. 2002. Differential induction of chorismate mutase isoforms by elicitors in oat leaves. Plant Physiol. Biochem. 40:795-802.

Meng, Y., Moscou, M. J., and Wise, R. P. 2009. Blufensin1 negatively impacts basal defense in response to barley powdery mildew. Plant Physiol. 149:271-285.

Mobley, E. M., Kunkel, B. N., and Keith, B. 1999. Identification, characterization and comparative analysis of a novel chorismate mutase gene in Arabidopsis thaliana. Gene 240:115-123.
Moseman, J. G. 1972. Isogenic barley lines for reaction to Erysiphe graminis f. sp. hordei. Crop Sci. 12:681-682.

Nafisi, M., Goregaoker, S., Botanga, C. J., Glawischnig, E., Olsen, C. E., Halkier, B. A., and Glazebrook, J. 2007. Arabidopsis cytochrome P450 monooxygenase 71A13 catalyzes the conversion of indole-3-acetaldoxime in camalexin synthesis. Plant Cell 19:2039-2052.

Niyogi, K. K., and Fink, G. R. 1992. Two anthranilate synthase genes in Arabidopsis: Defense-related regulation of the tryptophan pathway. Plant Cell 4:721-733.

Peterhansel, C., Freialdenhoven, A., Kurth, J., Kolsch, R., and SchulzeLefert, P. 1997. Interaction analyses of genes required for resistance responses to powdery mildew in barley reveal distinct pathways leading to leaf cell death. Plant Cell 9:1397-1409.

Ploubidou, A., and Way, M. 2001. Viral transport and the cytoskeleton. Curr. Opin. Cell Biol. 13:97-105.

Reimmann, C., and VanEtten, H. D. 1994. Cloning and characterization of the PDA6-1 gene encoding a fungal cytochrome P-450 which detoxifies the phytoalexin pisatin from garden pea. Gene 146:221-226.

Ridout, C. J., Skamnioti, P., Porritt, O., Sacristan, S., Jones, J. D. G., and Brown, J. K. M. 2006. Multiple avirulence paralogues in cereal powdery mildew fungi may contribute to parasite fitness and defeat of plant resistance. Plant Cell 18:2402-2414.

Schweizer, P., Pokorny, J., Schulze-Lefert, P., and Dudler, R. 2000. Double-stranded RNA interferes with gene function at the single-cell level in cereals. Plant J. 24:895-903.

Scofield, S. R., Huang, L., Brandt, A. S., and Gill, B. S. 2005. Development of a virus-induced gene-silencing system for hexaploid wheat and its use in functional analysis of the Lr21-mediated leaf rust resistance pathway. Plant Physiol. 138:2165-2173.

Shen, Q.-H., Saijo, Y., Mauch, S., Biskup, C., Bieri, S., Keller, B., Seki, H., Ulker, B., Somssich, I. E., and Schulze-Lefert, P. 2007. Nuclear activity of MLA immune receptors links isolate-specific and basal disease-resistance responses. Science 315:1098-1103.

Shirasu, K., Nielsen, K., Piffanelli, P., Oliver, R. P., and Schulze-Lefert, P. 1999a. Cell-autonomous complementation of mlo resistance using a biolistic transient expression system. Plant J. 17:293-299.

Shirasu, K., Lahaye, T., Tan, M. W., Zhou, F., Azevedo, C., and SchulzeLefert, P. 1999b. A novel class of eukaryotic zinc-binding proteins is required for disease resistance signaling in barley and development in C. elegans. Cell 99:355-366.

Stein, M., Dittgen, J., Sanchez-Rodriguez, C., Hou, B.-H., Molina, A., Schulze-Lefert, P., Lipka, V., and Somerville, S. 2006. Arabidopsis PEN3/PDR8, an ATP binding cassette transporter, contributes to nonhost resistance to inappropriate pathogens that enter by direct penetration. Plant Cell 18:731-746.

Thomma, B. P. H. J., Nelissen, I., Eggermont, K., and Broekaert, W. F. 1999. Deficiency in phytoalexin production causes enhanced susceptibility of Arabidopsis thaliana to the fungus Alternaria brassicicola. Plant J. 19:163-171.

Thordal-Christensen, H., Zhang, Z., Wei, Y., and Collinge, D. B. 1997. Subcellular localization of $\mathrm{H}_{2} \mathrm{O}_{2}$ in plants. $\mathrm{H}_{2} \mathrm{O}_{2}$ accumulation in papillae and hypersensitive response during the barley powdery mildew interaction. Plant J. 11:1187-1194.

Tozawa, Y., Hasegawa, H., Terakawa, T., and Wakasa, K. 2001. Characterization of rice anthranilate synthase \{alpha\}-subunit genes OASA1 and $O A S A 2$. Tryptophan accumulation in transgenic rice expressing a feedback-insensitive mutant of OASA1. Plant Physiol. 126:1493-1506.

van den Burg, H. A., Harrison, S. J., Joosten, M. H. A. J., Vervoort, J., and de Wit, P. J. G. M. 2006. Cladosporium fulvum Avr4 protects fungal cell walls against hydrolysis by plant chitinases accumulating during infection. Mol. Plant-Microbe Interact. 19:1420-1430.

Verchot-Lubicz, J., Ye, C.-M., and Bamunusinghe, D. 2007. Molecular biology of potexviruses: Recent advances. J. Gen. Virol. 88:1643-1655.

von Ropenack, E., Parr, A., and Schulze-Lefert, P. 1998. Structural analyses and dynamics of soluble and cell wall-bound phenolics in a broad spectrum resistance to the powdery mildew fungus in barley. J. Biol. Chem. 273:9013-9022.

Wise, R., and Ellingboe, A. H. 1983. Infection kinetics of Erysiphe graminis f. sp. hordei on barley with different alleles at the $\mathrm{Ml}$-a locus. Phytopathology 73:1220-1222.

Wolter, M., Hollricher, K., Salamini, F., and Schulze-Lefert, P. 1993. The mlo resistance alleles to powdery mildew infection in barley trigger a developmentally controlled defence mimic phenotype. Mol. Gen. Genet. 239:122-128.

\section{AUTHOR-RECOMMENDED INTERNET RESOURCES}

Clemson University Genomics Institute: www.genome.clemson.edu PLEXdb (Plant Expression database): www.plexdb.org/ 